\title{
sciendo
}

10.2478/jlecol-2019-0005

Journal of Landscape Ecology (2019), Vol: 12 / No. 1.

\section{THE POTENTIAL OF MANOR GARDENS FOR NATURAL HABITATS CONSERVATION}

\author{
MARKÉTA ŠANTRƯČKOVÁ ${ }^{1}$, KATARÍNA DEMKOVÁ ${ }^{1}$, JIŘÍ DOSTÁLEK ${ }^{1}$, \\ TOMÁŠ FRANTÍK ${ }^{2}$
}

\begin{abstract}
${ }^{1}$ Silva Tarouca Research Institute for Landscape and Ornamental Gardening, Květnové náměstí 391, CZ-252 43 Prühonice, Czech Republic

${ }^{2}$ Institute of Botany, Academy of Sciences of the Czech Republic, CZ-252 43 Prühonice, Czech Republic

*Corresponding authore-mail: santruckova@vukoz.cz
\end{abstract}

Received: $27^{\text {th }}$ September 2018, Accepted: $29^{\text {th }}$ November 2018

\begin{abstract}
Historical gardens established around manors form an integral part of the European cultural landscape. Recent studies have revealed that manor gardens may serve as local hotspots of biodiversity and provide cultural ecosystem services within urban areas but also in rural landscapes. As a consequence of dramatic land-use changes in recent centuries, followed by a significant loss and degradation of natural habitats, manor gardens often serve as refugia for organisms within the cultural landscape. To compare the proportion of natural habitats in manor gardens with the surrounding landscape, intensively used and semi-natural landscapes were distinguished within a grid using Coordinated Information on the Environment (CORINE) land cover data for the Czech Republic. One hundred manor gardens were randomly selected, followed by a grid overlay of data from the Natura 2000 mapping system. Proportions of natural habitats were calculated for each garden in relation to the surrounding landscape. The results confirmed that manor gardens, compared with the surrounding landscape, play an important role in the conservation of natural habitats, especially in areas with a high level of human impact. For the gardens studied, occurrences of the following natural habitat types from the Natura 2000 system were recorded: forests ( $25.4 \%$ of the garden area), secondary grasslands $(4.4 \%)$, streams and water bodies $(1.6 \%)$ and wetlands and riverine vegetation $(0.5 \%)$. The proportion of natural habitats within the gardens compared to the surrounding areas was significantly higher in the majority of cases.
\end{abstract}

Keywords: manor gardens, natural habitats conservation, human impact, NATURA 2000, Czech Republic

\section{INTRODUCTION}

In connection with land-use changes in the cultural landscape, a significant loss and degradation of natural habitats has occurred (e.g., Krebs et al., 1999; Sklenička et al., 2009; Vos \& Meekes, 1999). For example, in the Czech Republic, significant natural habitat decreases began by the mid- $19^{\text {th }}$ century due to intensive farming of the landscape (Šantrůčková et al., 2015). Indeed, the fragmentation and loss of natural habitats is one of the principle challenges for plant biodiversity conservation and is connected to the 
environmental degradation that occurred in Europe during the second half of $20^{\text {th }}$ century, primarily due to intensified agricultural land management practices and increased urbanization (e.g., Benton et al., 2003; Donald et al., 2006; Henle et al., 2008; Van Calster et al., 2008). Thus, natural habitat conservation within intensively managed cultural landscapes is a constant concern.

Historical gardens established around manors and castles in the $16^{\text {th }}-19^{\text {th }}$ centuries form an integral part of the European cultural landscape. Attention is particularly focused on its cultural heritage and aesthetic-recreational value (Cranz \& Boland, 2004). A recent study revealed that manor gardens may also serve as local hotspots of biodiversity and provide cultural ecosystem services within urban areas (e.g., Andersson et al., 2015; Chiesura, 2004; Cornelis \& Hermy, 2004; Hermy \& Cornelis, 2000; Kowarik et al., 1998; Kümmerling \& Müller, 2012; Langemeyer et al., 2015) but also in rural landscapes (Liira et al., 2012; Lõhmus \& Liira, 2013; Walerzak et al., 2015; Šantrůčková et al., 2017). In many cases, during the manor garden creation, the local natural habitats (e.g., species-rich meadows and natural forests) were incorporated to increase the overall value of the garden. Additionally, due to longtime, nature-friendly management techniques, the newly established meadows and tree plantations began functioning as natural meadow and forest habitats within the less intensely managed sections (Glendel \& Vaughan, 2002; Jonsell, 2012; Liira et al., 2012). In particular, the landscape gardens are an example of how appropriate, initial sustainable design can provide important areas for biological conservation (Kümmerling \& Müller, 2012). However, some studies have noted that horticultural introductions and widespread plantings in these gardens may actually function as starting points for the undesirable hybridization of native and non-native species resulting in biological invasions, which are widely acknowledged as a major threat to biodiversity (Dehnen-Schmutz et al., 2007; Kowarik, 2005; Mack \& Erneberg, 2002; Reichard \& White, 2001; Säumel et al. 2010). Further, despite a rising number of research studies concerning gardens and biodiversity, there remains a lack of general knowledge about the position of historical gardens in comparison with the surrounding landscape.

Based on an assessment of our data, the paper is focused on: 1. assessment of the proportion of natural habitats in manor gardens in comparison with the surrounding landscape, and 2. enhancement of the position of manor gardens as natural habitat refugia in landscapes with a high level of human impact in comparison with those having a low level of human impact.

\section{STUDY AREAS}

Manor gardens are dispersed throughout the entire territory of the Czech Republic. The gardens were planted mainly between the $17^{\text {th }}$ and $19^{\text {th }}$ centuries. Landscape gardens are the most common type because they are the last universal garden design. Only a few Baroque and Renaissance gardens are preserved in their former appearance. In terms of land area, the gardens differ markedly: the model sample ranges from 0.06 ha to 288 ha, where the average size is $\mathbf{1 5 . 5}$ ha. The most numerous are small, manor gardens (median of the model sample is $6.1 \mathrm{ha}$ ) within villages and small towns that obtain only limited, basic maintenance. On the other hand, large gardens appear less frequently, and the level of maintenance for them is uneven. Some are used intensively and frequently visited. For example, these gardens may experience the construction of new playgrounds, intensive planting of trees and shrubs and the use of chemicals in caring for grasslands. At the same time, some of the gardens are left almost completely without care where grasslands, old solitaire trees and groves become overgrown and degraded due to natural seeding (Šantrůčková, 2012). 


\section{DATA AND METHODS}

\section{Data sources}

Coordinated Information on the Environment (CORINE) land cover data 2006 (European Environmental Agency) is a vector map with a scale of 1:100 000 and a minimum cartographic unit of 25 ha and has a geometric accuracy better than $100 \mathrm{~m}$. It maps homogeneous landscape patterns: for example, areas having more than $75 \%$ of a particular pattern have the characteristics of a given, named class. To address areas smaller than 25 ha a set of generalization rules were defined (EEA, 2007). The CORINE land cover nomenclature is a 3-level hierarchical classification system and has 44 classes at the third and most detailed level. In the Czech Republic, 28 classes were identified at the third level. The data were used to identify the level of human impact on landscapes of the Czech Republic.

Natural habitats mapping data of the Agency for Nature Conservation and Landscape Protection (C AOPK) was used to assess the natural habitat proportions. The data consisted of a digitized vector output for the Czech Republic at a scale of 1:10 000. It was developed during the establishment of Natura 2000 (according the Habitat Direction). Natural habitats are classified according to Chytrý et al. (2010). The May 2014 database version was used for analysis.

A database of the historic gardens of the Czech Republic contains a point dataset of the historic gardens in geographic information systems (GIS) as well as text sheets. The database was created by the Research Institute of Landscape and Ornamental Gardening (VUKOZ) during the 2000s according to old and new encyclopedias of garden art monuments in the Czech Republic, in addition to other literature. For this research, manor gardens were selected from the database according the item "type of the garden art monument" (total 700 items).

The demographic database of the Czech Statistical Agency (CSU) provides data about population development for municipalities in the Czech Republic. We used the total population number of the municipalities in which the gardens are situated as of $31^{\text {st }}$ December 2014. The correlation between the population strength of the settlement and the presence of natural habitats in the manor gardens was investigated.

\section{Data processing}

First, the territory of the Czech Republic was overlaid with a square grid, which divided the country into squares of ten longitudinal and six latitudinal minutes (approximately $133.5 \mathrm{sq}$. $\mathrm{km}$ ) to create an independent, spatial dimension. To distinguish intensively used landscapes from semi-natural and "natural" landscapes, CORINE land cover data were used. Classes at the third level were applied to calculate the index of anthropogenic impact on vegetation (Löw et al., 1995) for each square:

$$
\mathrm{K}_{\mathrm{aiv}}=\mathrm{N} * \mathrm{~A}^{-1}
$$

where $\mathrm{N}$ represents natural or semi-natural areas (forest, shrubs, grasslands, wetlands and water bodies),

A represents artificial surfaces (urban spaces, mine sites, sport and leisure facilities, etc.) and agricultural areas (arable land, gardens, orchards and vineyards, etc.)

and $\mathrm{K}_{\mathrm{aiv}}$ is a measure of human impact on ecosystems. Specifically, it expresses the proportion of natural or semi-natural ecosystems to artificial ecosystems. The results are classified according to a five-item scale. For the purposes of this study, five levels were reduced to two levels - landscapes with high level of human impact and landscapes with a low level of human impact (Table 1). 
Table 1: Levels of human impact on the landscape - $K_{\text {aiv }}$ (Löw et al., 1995)

\begin{tabular}{|l|l|l|}
\hline Value & Level & Level in the study \\
\hline$\leq 0,4$ & Very high impact & \multirow{2}{*}{ High human impact } \\
\hline $0,41-0,80$ & High impact & \multirow{2}{*}{ Low human impact } \\
\hline $0,81-1,2$ & Medium/mean impact & \\
\hline $1,21-2,00$ & Low impact & \\
\hline $2,00<$ & Very low impact &
\end{tabular}

Second, we selected 100 gardens throughout the Czech Republic (Fig. 1). 50 objects at each level of human impact were randomly selected from the point database of manor gardens using Hawth's Analysis Tools for ArcGIS (Beyer, 2007). Both samples cover the diversity and typical features of the manor gardens in the Czech Republic. Afterwards, selected gardens were digitized using a basic map of the Czech Republic at a scale of 1:10 000 (Czech Environmental Information Agency) and Stable cadaster maps at a scale of 1:2880 (State Administration of Land Surveying and Cadastre) as the background. After digitization, only squares intersected by digitized gardens were counted. In two cases, gardens crossed into squares having different levels of human impact; therefore, they were removed from the dataset.

Subsequently, the selected squares were overlaid with natural habitat mapping data, and proportions of natural habitats were calculated for each garden and surrounding landscape in squares.

Fig. 1: Location of sampled manor gardens in the Czech Republic used in the analysis.

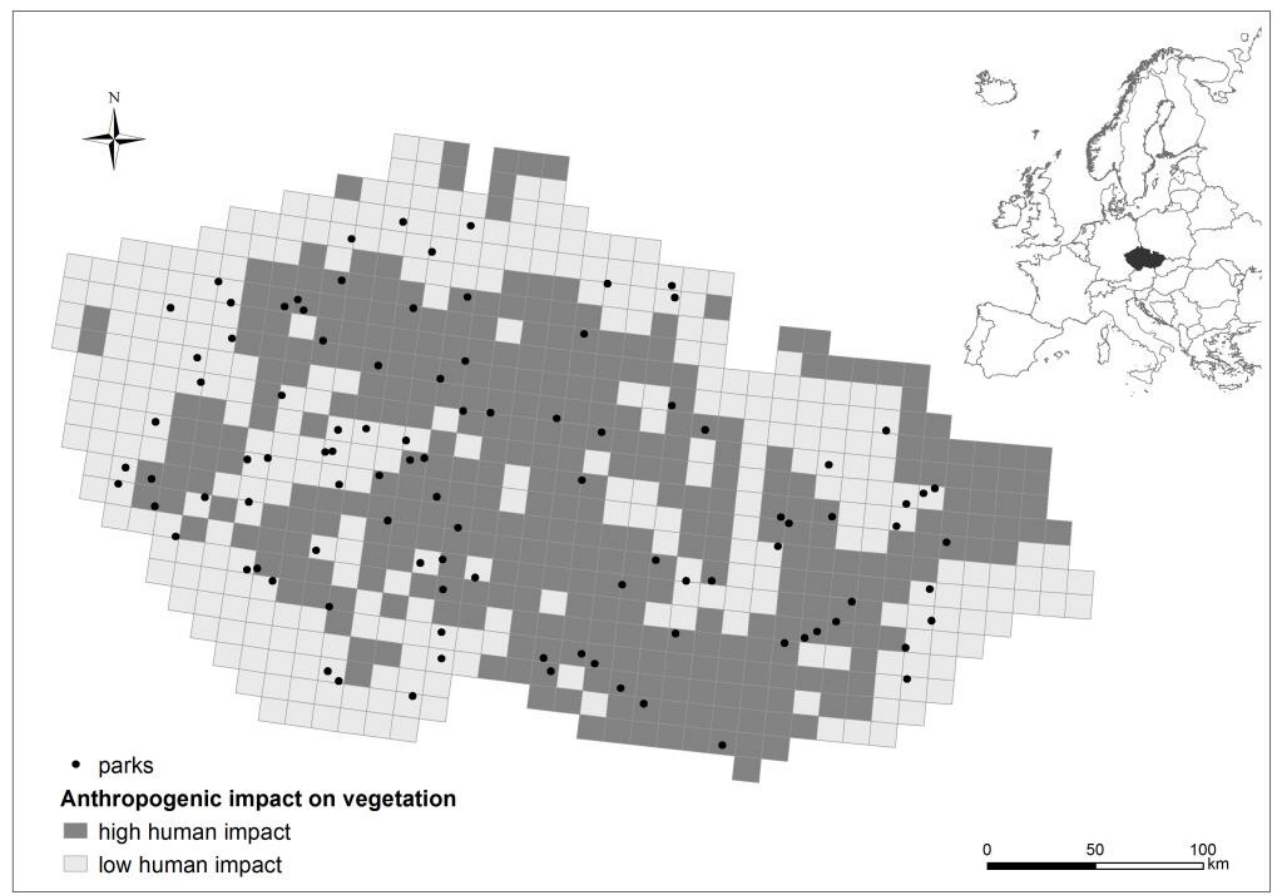




\section{Statistical analysis}

First, a gradient analysis of natural habitat types within the gardens was completed. A canonical analysis using the CANOCO 5 software (Ter Braak \& Šmilauer, 2012) was conducted for (1) the proportion of natural habitat formation groups and (2) selected forest and secondary grassland habitat groups. The purpose was to identify their relation to the level of human impact and the gradient of habitation in the vicinity and garden areas.

Second, the manor gardens and surrounding landscapes were compared. Proportions of natural habitat types in gardens versus squares were calculated according to the Wilcoxon test separately for landscapes with high and low levels of human impact.

Finally, landscapes with a high and low level of human impact were compared. The difference in proportion of habitat in a garden versus the surrounding landscape was calculated by subtracting. The importance of manor gardens as natural habitat refugia was then compared according to analysis of variance (ANOVA) in the case of homogeneity of variances or, in other cases, according to the Mann-Whitney test for landscapes with high and low levels of human impact. The software program STATISTICA v. 9.0 (StatSoft Inc., 2009) was used for the statistical analyses.

\section{RESULTS}

The difference between the proportion of natural habitats in gardens and their surrounding areas in landscapes with a high level of human impact is significantly higher than the difference found in landscapes having a low level of human impact (Table 2). This indicates a stronger importance of gardens as natural habitat refugia in landscapes having a high level of human impact. However, the data evaluation did not show any statistically significant differences in the overall proportion of natural habitats in gardens and the surrounding landscape for the intersected squares (Fig. 2).

Fig. 2: Proportion of natural habitats in manor gardens and surrounding landscape (squares) having a high and low level of human impact.

Differences between gardens and surrounding landscape are statistically insignificant.

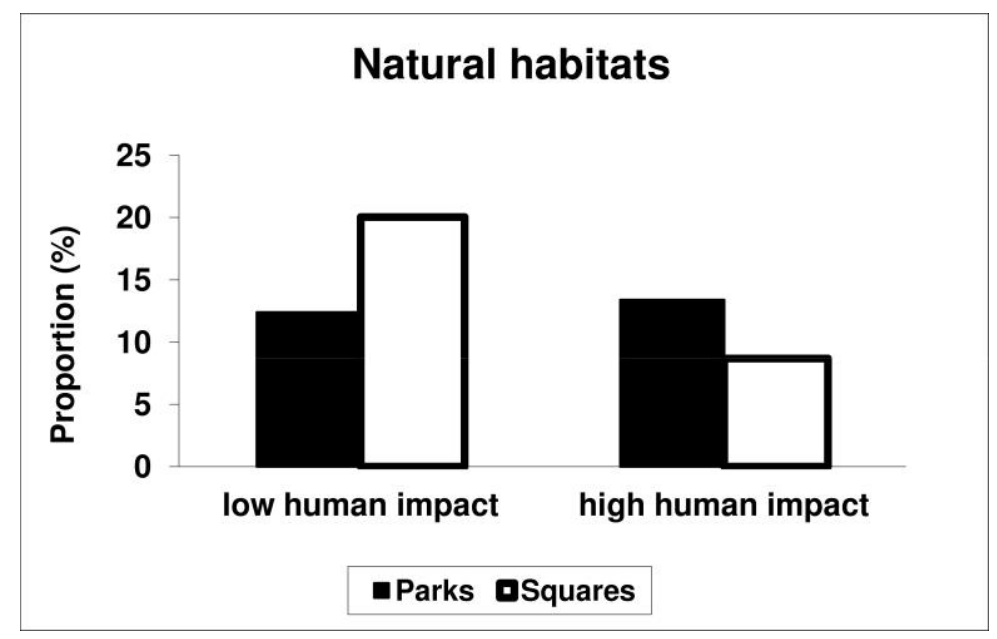


Šantrůčková M. et al. .: The potential of manor gardens for natural habitats conservation

Table 2: Differences in habitat proportion for gardens and surrounding landscapes comparison of landscapes having high and low levels of human impact (significant values are highlighted in bold)

\begin{tabular}{|l|l|l|l|}
\hline \multirow{2}{*}{ Habitat name } & \multicolumn{2}{|l|}{$\begin{array}{l}\text { Difference of habitat proportion in a garden and } \\
\text { a surrounding landscape (\%) }\end{array}$} & \multirow{2}{*}{ Statistical significance } \\
\cline { 2 - 4 } & High human impact & Low human impact & \\
\hline Natural habitats & 4.7 & -7.6 & $\mathbf{0 . 0 1 1}$ \\
\hline Forests & 2.6 & -1.5 & 0.267 \\
\hline $\begin{array}{l}\text { Wetlands and riverine } \\
\text { vegetation }\end{array}$ & -0.1 & 0.6 & 0.399 \\
\hline Secondary grasslands & 1.5 & -6.0 & $\mathbf{0 . 0 0 1}$ \\
\hline $\begin{array}{l}\text { Streams and water } \\
\text { bodies }\end{array}$ & 0.1 & 0.4 & 0.522 \\
\hline $\begin{array}{l}\text { Alder carrs and alluvial } \\
\text { forests }\end{array}$ & 0.6 & 0.4 & 0.904 \\
\hline $\begin{array}{l}\text { Oak-hornbeam and oak } \\
\text { forests }\end{array}$ & 2.4 & 0.4 & 0.418 \\
\hline Ravine forests & 0.0 & -0.7 & $\mathbf{0 . 0 0 0}$ \\
\hline Beech forests & -0.4 & -4.7 & $\mathbf{0 . 0 0 3}$ \\
\hline $\begin{array}{l}\text { Mesic and montane } \\
\text { meadows }\end{array}$ & 1.3 & -0.1 & $\mathbf{0 . 0 0 0}$ \\
\hline $\begin{array}{l}\text { Alluvial Alopecurus } \\
\text { meadows }\end{array}$ & 0.8 & -2.5 & 0.385 \\
\hline $\begin{array}{l}\text { Wet meadows, } \\
\text { vasslands and tall-forb }\end{array}$ & -0.4 & -5 & \\
\hline
\end{tabular}

For the gardens in this study, occurrence was recorded for the following, which mostly represented formation groups of the Natura 2000 system of natural habitats: forests (total proportion $25.4 \%$ of the garden area), secondary grasslands $(4.4 \%)$, streams and water bodies $(1.6 \%)$ and wetlands and riverine vegetation $(0.5 \%)$.

\section{Forests}

Generally, forest stands are more frequently present in gardens located within smaller population centers (Fig. 3). The CA results indicate that larger gardens in landscapes of low human impact serve as refuges for beech and ravine forests. The population number does not influence their proportion in the gardens. Furthermore, alder carrs and alluvial forests, in addition to oak-hornbeam and oak forests, are not correlated with any factor tested (Fig. 4). 
Fig. 3: The results of an unconstrained unimodal gradient analysis (CA) show the relation of the proportion of natural habitat formation groups in manor gardens versus the level of human impact, garden area and vicinity habitation.

The first and second axes explain $72 \%$ of total variation. The level of human impact, garden area and vicinity habitation account for $7 \%$ of total variation.

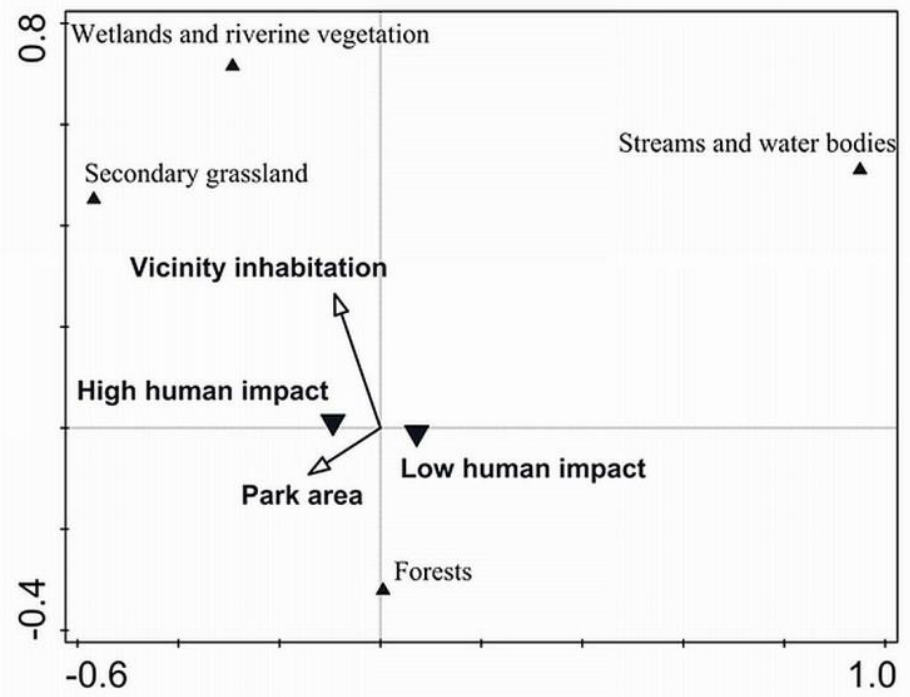

Fig. 4: The results of an unconstrained unimodal gradient analysis (CA) show the relation of the proportion of forests and secondary grassland natural habitat groups in manor gardens versus the level of human impact, garden area and vicinity habitation. First and second axis explained $51 \%$ of total variation. The level of human impact, garden area and vicinity habitation account for $25 \%$ of total variation.

Abbreviations: $\mathrm{BF}$ - beech forests, $\mathrm{RF}$ - ravine forests, O-HOF - oak-hornbean and oak forests, ACAF - alder carrs and alluvial forests, MMM - mesic and montane meadows, WMGT-FV - wet meadows, grasslands and tall-forb vegetation, AAM - alluvial Alopecurus meadows.

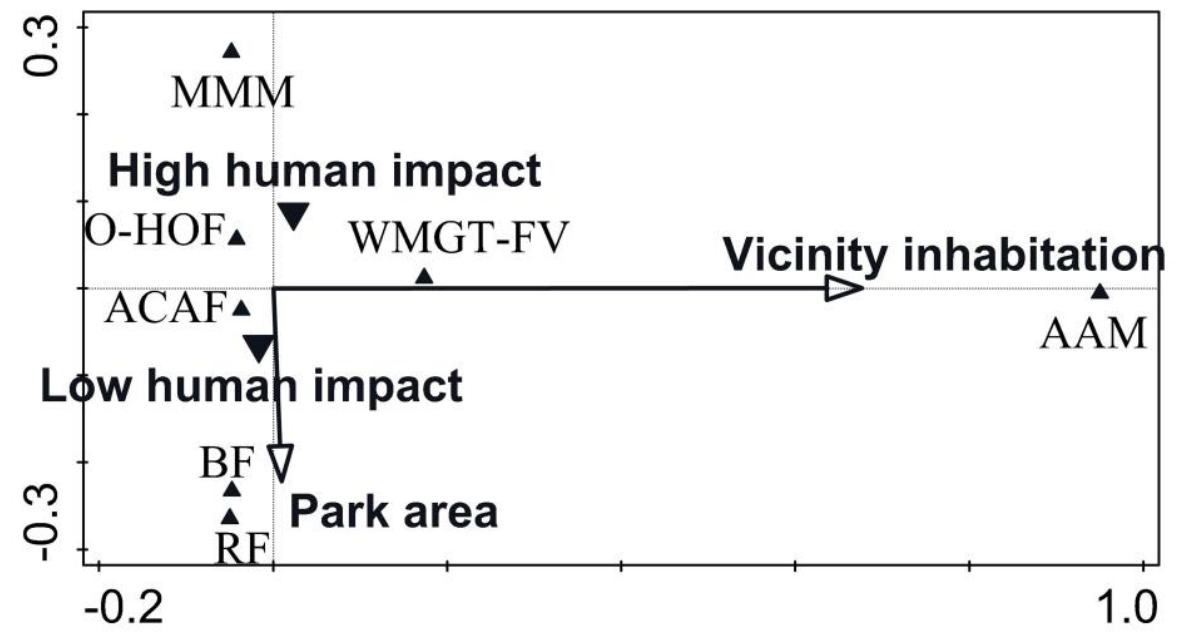


Forests are more frequent in gardens than in surrounding landscapes having a high level of human impact (Fig. 5). For instance, a higher proportion of ravine forests, alder carrs and alluvial forests, as well as oak-hornbeam and oak forests was found in gardens in comparison with surrounding landscapes having both high and low levels of human impact. In contrast, no significant differences were found for the proportion of beech forests in gardens versus the surrounding landscape (Fig. 5). However, the difference between the proportion of beech forest in gardens in comparison with surrounding areas was significantly higher in landscapes with a high level of human impact (i.e., less negative) in relation to landscapes with a low level of human impact (Table 2). Finally, the proportion of ravine forests in landscapes with a high level of human impact is negligible, while the difference between the proportion of ravine forest in gardens versus the surrounding area shows an opposite tendency to that of beech forest.

Fig. 5: Proportion of forest habitats in manor gardens and surrounding landscape (squares) with high and low levels of human impact.

Statistically significant differences between gardens and the surrounding landscapes are marked with asterisks.

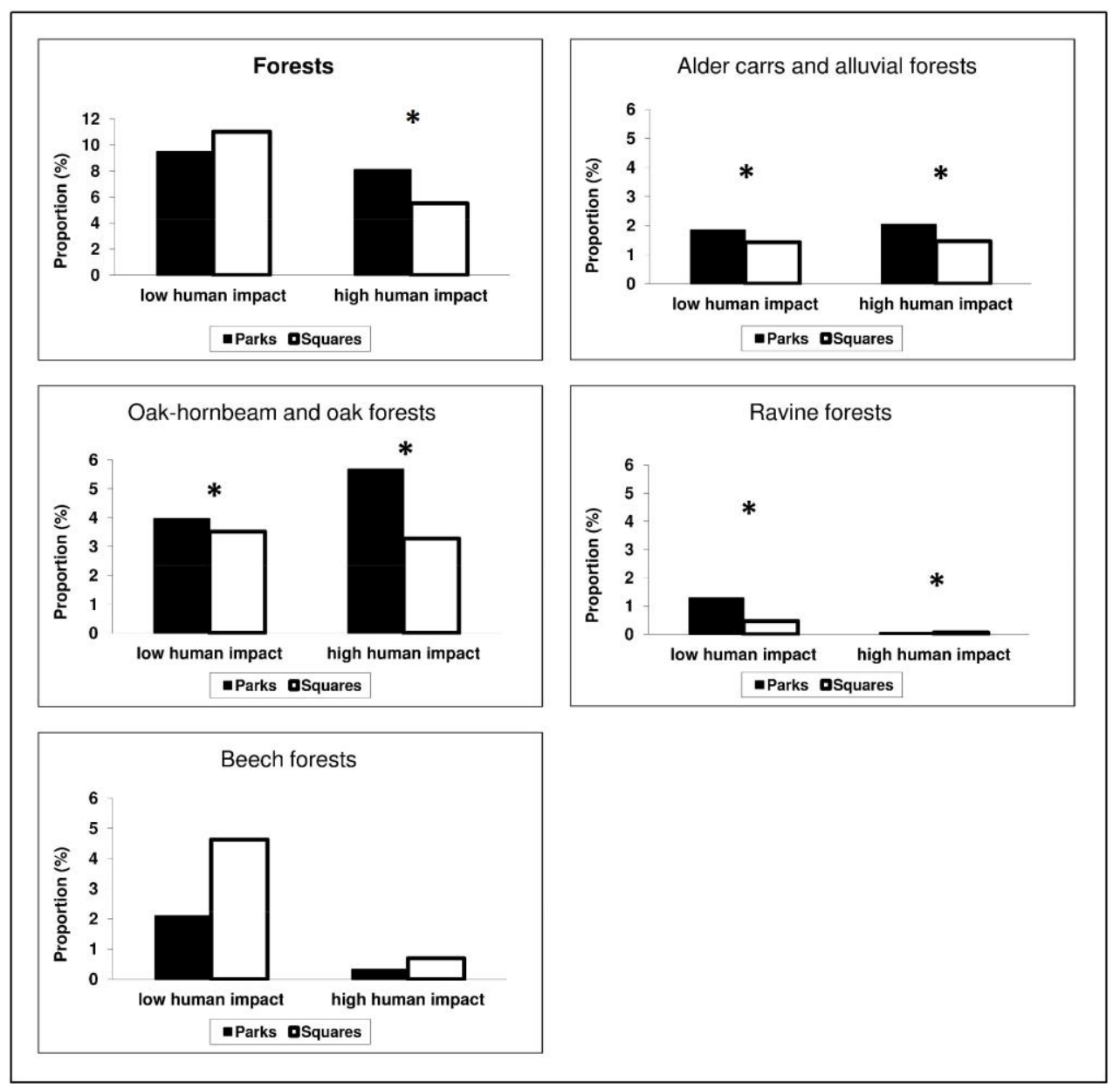




\section{Secondary grasslands}

CA analysis results show that secondary grasslands are present more frequently in gardens in landscapes with a high level of human impact that are near human settlements with a higher population. However, the garden area does not have an impact on the proportion of secondary grasslands (Fig. 3). The CA results also indicate that the occurrence of mesic and montane meadows is related to smaller gardens. Wet meadows, grasslands and tall-forb vegetation, as well as alluvial Alopecurus meadows, are found more frequently in gardens with a higher number of nearby inhabitants. Moreover, their frequency does not depend on either human impact or garden area (Fig. 4).

Secondary grasslands are more frequent in gardens than in surrounding landscapes with a high level of human impact (Fig. 6). In addition, the difference between the proportion of secondary grasslands in gardens with a surrounding landscape having a high level of high human impact is higher than those with a low level of human impact (Table 2).

Fig. 6: Proportion of secondary grasslands habitats in manor gardens and surrounding landscape (squares) with high and low levels of human impact.

Statistically significant differences between gardens and surrounding landscapes are marked with asterisks

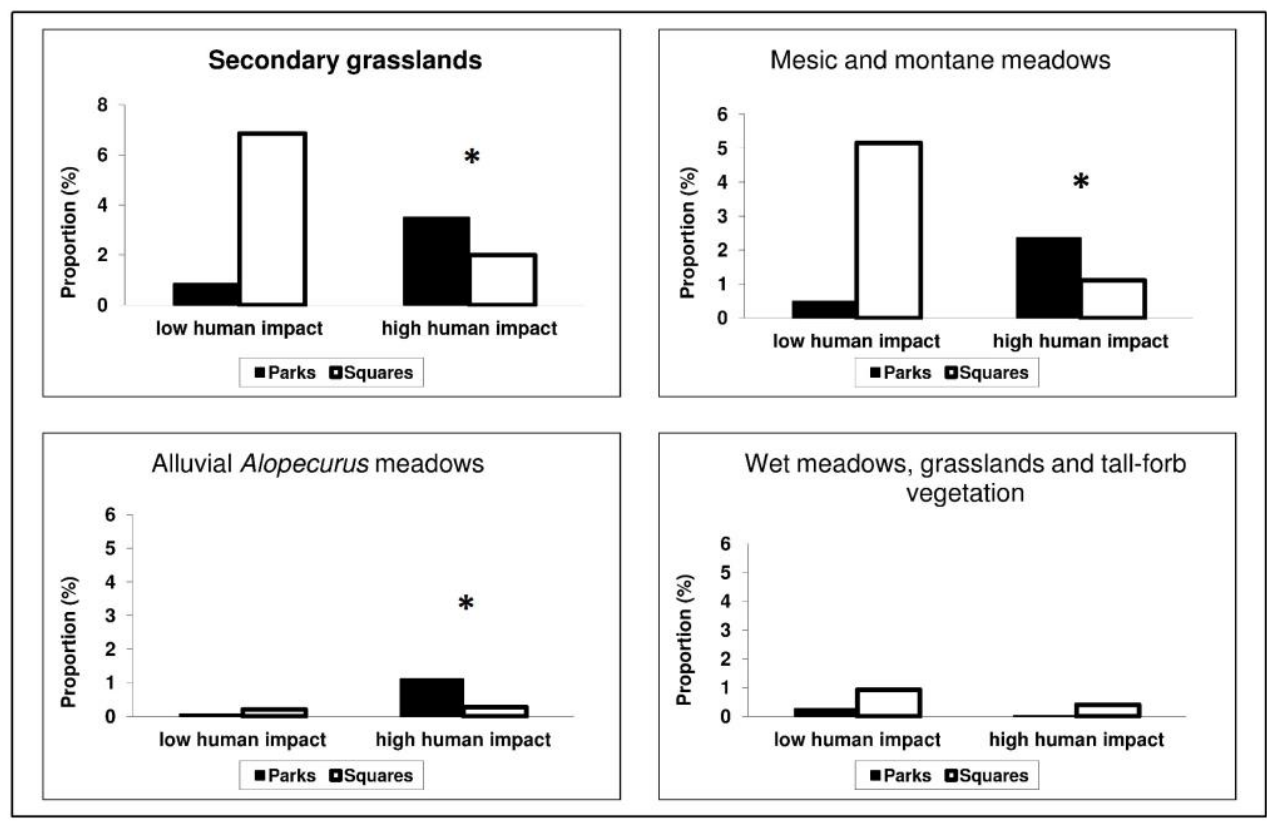

Finally, mesic and montane meadows, as well as alluvial Alopecurus meadows, showed a higher proportion in gardens than in surrounding landscapes with of high level of human impact (Fig. 6). The difference between the proportion of wet meadows, grasslands and tall-forb vegetation and mesic and montane meadows in gardens with surrounding landscapes having a high level of human impact is significantly higher than that of landscapes with a low level of human impact (Table 2). 


\section{Water and wetland habitats}

CA results show that wetlands and riverine vegetation are present more frequently in gardens that are near settlements with a higher population. The garden area does not have an impact on their proportion (Fig. 3). Additionally, gardens play an important role as refuges for wetlands and riverine vegetation, especially for landscapes having a low level of human impact where the proportion of wetlands and riverine vegetation is higher in gardens than in the surrounding landscape (Fig. 7). However, the difference between the proportion of wetlands and riverine vegetation in gardens and their surrounding areas in landscapes having a low level of human impact is not significantly higher than those with a high level of human impact (Table 2).

Fig. 7: Proportion of water and wetland habitats in manor gardens and surrounding landscape (squares) having high and low levels of human impact.

Statistically significant differences between gardens and surrounding landscapes are marked with asterisks.

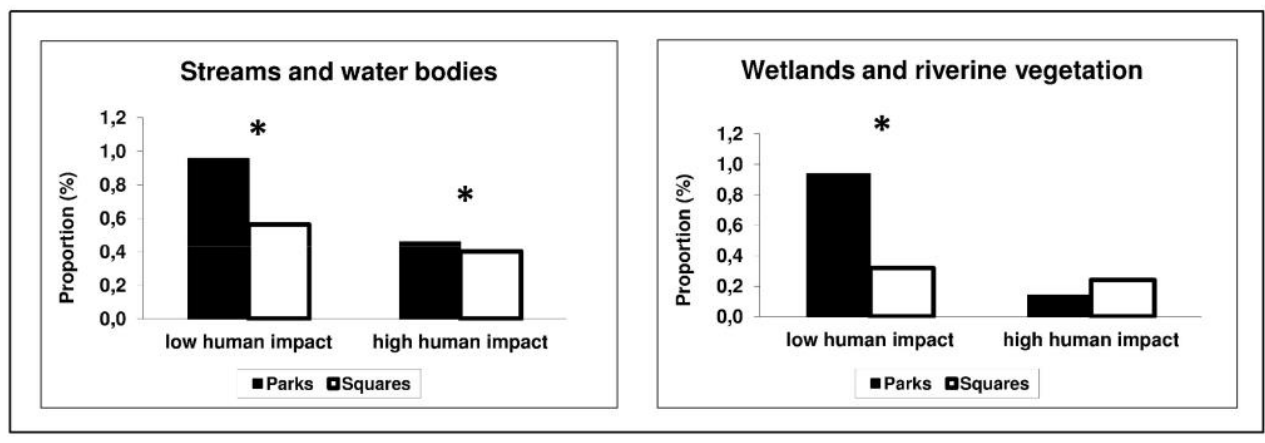

Further, streams and water bodies are bound to smaller gardens found in landscapes having a low level of human impact. At the same time, their presence does not significantly depend on the population number of surrounding municipalities (Fig. 3). Indeed, streams and water bodies are more frequent in gardens than in surrounding landscapes having both a high and low level of human impact (Fig. 7).

\section{DISCUSSION}

Several investigations of flora and vegetation in European historical gardens pointed a richness in native plant species and the capability of the gardens to sustain endangered habitats, including their biodiversity (Ignatieva \& Konechnaya, 2004; Müller \& Waldert, 1998; Peschel, 2000; Sukopp, 1968, Šantrůčková et al., 2017). Liira et al. (2012) highlighted the role of forest-like stands in old manor gardens for conservation of forest-specialist species. Kümmerling and Müller (2012) also documented the link between the historical design and management of gardens and rare species that inhabit rich grasslands.

The results of our study are consistent with the hypothesis that historical gardens act as important natural habitat refuge areas because of the decline of such refuges in today's rural landscape, especially in areas having a high level of human impact. Additionally, we found that the proportion of natural habitats in gardens is very often significantly higher in comparison with the surrounding landscape, especially in areas having a high level of human impact. 
A higher proportion of streams and water bodies in gardens in comparison with surrounding landscapes confirms the hypothesis of Kowarik (1998), who emphasized the importance of gardens for the conservation of water habitats. A higher proportion of wetlands and riverine vegetation in gardens in areas having a low level of human impact can be explained by either a more extensive or insufficient management of gardens and by the vicinity of smaller settlements. This, in connection with the lack of appropriate management during the communist era, has been and continues to generally be the case. However, secondary grasslands are more frequent in areas having a high level of human impact in comparison with the surrounding landscape. It is possible that garden management in these areas tends to be more intensive, where vegetation is mowed regularly, contributing to the prosperity of species-rich meadows. Indeed, the special conservation value of Potsdam's gardens for many types of endangered grasslands has been documented by Peschel (2000), while species-rich grasslands have also been reported in gardens located in Berlin (Sukopp, 1968) and Augsburg (Müller \& Waldert, 1998).

Concerning forests, we confirmed the findings of Liira et al. (2012) that manor gardens can serve as forest natural habitat refuges. Evaluation of our data indicated that except for beech forests, the proportion of the most frequently represented forest habitats in gardens is significantly higher than in the surrounding landscape. Additionally, the prosperity of beech forests and ravine forests is better supported by larger gardens, likely enjoying a lower management intensity. Indeed, Lõhmus \& Liira (2013) have expressed their hypothesis that old manor garden plantations have existed long enough to have at least a minimal level of habitat quality that allows the successful colonization of forest-dwelling species. This depends mostly on connectivity, time, optimal stand structure and management-disturbance intensity (Brunet et al., 2011; Gauslaa et al., 2007; Hartley, 2002; Jacquemyn et al., 2003; Nordén \& Appelqvist, 2001; Vojta \& Drhovská, 2012). However, it is necessary to consider that in many cases, local native forest remnants with well-preserved species compositions were used when gardens were being constructed, especially larger gardens.

\section{CONCLUSION}

The results confirmed that manor gardens, compared with the surrounding landscapes, play an important role in the conservation of natural habitats. Based on the comparison of a select proportion of natural habitat types (sensu Natura 2000) in gardens and surrounding landscapes in the Czech Republic, it was documented that:

1. Manor gardens as natural habitat refuges are more important in landscapes having of high level of human impact than those having a low level of human impact.

2. Streams and water bodies, alder carrs and alluvial forests, oak-hornbeam and oak forests and ravine forests are relatively more frequent in gardens than in the surrounding landscape, regardless of the level of human impact. However, no differences have been confirmed for beech forests for either their proportion in gardens or the surrounding landscapes.

3. Wetlands and riverine vegetation are relatively more frequent in gardens than in surrounding landscapes having a low level of human impact. In contrast, mesic and montane meadows in addition to alluvial Alopecurus meadows are relatively more frequent in gardens than in surrounding landscapes having a high level of human impact. 


\section{ACKNOWLEDGEMENT}

This research was funded by institutional support from the Silva Tarouca Research Institute for Landscape and Ornamental Gardening (VUKOZ-IP-00027073) and by a long-term research project of the Institute of Botany, Academy of Sciences of the Czech Republic (no. RVO 67985939).

Authors thank to the Agency for Nature Conservation and Landscape Protection for providing the data.

\section{REFERENCES}

Andersson, E., Tengö, M., McPhearson, T. \& Kremer, P. (2015). Cultural ecosystem services as a gateway for improving urban sustainability. Ecosyst. Services 12, 165-168. DOI: 10.1016/j.ecoser.2014.08.002.

Benton, T. G., Vickery, J. A. \& Wilson, J. D. (2003). Farmland biodiversity: is habitat heterogeneity the key? Trends Ecol. Evol. 18, 182-188. DOI: 10.1016/S0169-5347(03)00011-9.

Beyer, H. (2007, June). Hawth's Analysis Tools for ArcGIS. Retrieved June 12, 2015, from http://www.spatialecology.com

Brunet, J., Valtinat, K., Mayr, M. L., Felton, A., Lindbladh, M. \& Bruun, H. H. (2011). Understory succession in post-agricultural oak forests: habitat fragmentation affects forest specialists and generalists differently. Forest Ecol. Manag. 262, 1863-1871. DOI: 10.1016/j.foreco.2011.08.007.

Chiesura, A. (2004). The role of urban parks for the sustainable city. Landsc. Urban Plan. 68, 129-138. DOI: 10.1016/j.landurbplan.2003.08.003.

Chytrý, M. (2012). Vegetation of the Czech Republic: diversity, ecology, history and dynamics. Preslia, 84, 427-504.

Chytrý, M., Kučera, T., Kočí, M., Grulich, V. \& Lustyk, P. (2010). Katalog biotopů České republiky $\left(2^{\text {nd }}\right.$ ed.). Praha: Agentura ochrany přírody a krajiny ČR.

Cornelis, J. \& Hermy, M. (2004). Biodiversity relationships in urban and suburban parks in Flanders. Landsc. Urban Plan. 69, 385-401. DOI: 10.1016/j.landurbplan.2003.10.038.

Cranz, G. \& Boland, M. (2004). Defining the sustainable park: a fifth model for urban parks. Landscape J. 23, 102-120. DOI: 10.3368/1j.23.2.102.

CUZK (2014). Souhrnné přehledy o půdním fondu z údajů katastru nemovitostí České republiky. Praha: ČÚZK.

Dehnen-Schmutz, K., Touza, J., Perrings, C. \& Williamson, M. (2007). The horticultural trade and ornamental plant invasions in Britain. Conserv. Biol. 21, 224-231. DOI: $10.1111 /$ j.1523-1739.2006.00538.x.

Donald, P. F., Sanderson, F. J., Burfield, I. J. \& Van Bommel, F. P. (2006). Further evidence of continent-wide impacts of agricultural intensification on European farmland birds, 1990 2000. Agr. Ecosyst. Environ. 116, 189-196. DOI:10.1016/j.agee.2006.02.007.

EEA (2007, June). CLC2006 technical guidelines. EEA Technical report, No. 17, 70 p. Retrieved June 12, 2015, from http://www.eea.europa.eu/data-and-maps

Gauslaa, Y., Palmqvist, K., Solhaug, K. A., Holien, H., Hilmo, O., Nybakken, L., Myhre, L. C. \& Ohlson, M. (2007). Growth of epiphytic old forest lichens across climatic and successional gradients. Can. J. Forest Res. 37, 1832-1845. DOI: 10.1139/X07-048. 
Glendell, M. \& Vaughan, N. (2002). Foraging activity of bats in historic landscape parks in relation to habitat composition and park management. Anim. Conserv. 5, 309-316. DOI: http://dx.doi.org/10.1017/S1367943002004067.

Hartley, M. J. (2002). Rationale and methods for conserving biodiversity in plantation forests. Forest Ecol. Manag. 155, 81-95. DOI: 10.1016/S0378-1127(01)00549-7.

Henle, K., Alard, D., Clitherow, J., Cobb, P., Firbank, L., Kull, T., McCracken, D., Moritz, R. F. A., Niemelä, J., Rebane, M., Wascher, D., Watt, A. \& Young, J. (2008). Identifying and managing the conflicts between agriculture and biodiversity conservation in Europe - A review. Agr. Ecosyst. Environ. 124, 60-71. DOI: 10.1016/j.agee.2007.09.005.

Hermy, M. \& Cornelis, J. (2000). Towards a monitoring method and a number of multifaceted and hierarchical biodiversity indicators for urban and suburban parks. Landsc. Urban Plan. 49, 149-162. DOI: 10.1016/S0169-2046(00)00061-X.

Ignatieva, M. \& Konechnaya, G. (2004). Floristic investigations of historical parks in St. Petersburg, Russia. Urban Habitats, 2, 174-216.

Jacquemyn, H., Butaye, J. \& Hermy, M. (2003). Influence of environmental and spatial variables on regional distribution of forest plant species in a fragmented and changing landscape. Ecography, 26, 768-776. DOI: 10.1111/j.0906-7590.2003.03620.x.

Jonsell, M. (2012). Old park trees as habitat for saproxylic beetle species. Biodivers. Conserv. 21, 619-642. DOI: 10.1007/s10531-011-0203-0.

Kowarik, I. (1998). Historische Gärten und Parkanlagen als Gegenstand eines Denkmal-orientierten Naturschutzes. In I. Kowarik, E. Schmidt \& B. Sigel (Eds.), Naturschutz und Denkmalpflege. Wege zu einem Dialog im Garten (pp. 111-139). Zürich: Hochschulverlag Zürich.

Kowarik, I. (2005). Urban ornamentals escaped from cultivation. In J. Gressel (Ed.), Crop Ferality and Volunteerism (pp. 97-121). Boca Raton: CRC Press.

Krebs, J. R., Wilson, J. D., Bradbury, R. B. \& Siriwardena, G. M. (1999). The second silent spring? Nature, 400, 611-612. DOI: 10.1038/23127.

Kümmerling, M. \& Müller, N. (2012). The relationship between landscape design style and the conservation value of parks: A case study of a historical park in Weimar, Germany. Landsc. Urban Plan. 107, 111-117. DOI: 10.1016/j.landurbplan.2012.05.006.

Langemeyer, J., Baró, F., Roebeling, P. \& Gómez-Baggethun, E. (2015). Contrasting values of cultural ecosystem services in urban areas: The case of park Montjuïc in Barcelona. Ecosyst. Services, 12, 178-186. DOI: 10.1016/j.ecoser.2014.11.016.

Liira, J., Lõhmus, K. \& Tuisk, E. (2012). Old manor parks as potential habitats for forest flora in agricultural landscapes of Estonia. Biol. Conserv. 146, 144-154. DOI: 10.1016/j.biocon.2011.11.034.

Lõhmus, K. \& Liira, J. (2013). Old rural parks support higher biodiversity than forest remnants. Basic Appl. Ecol. 14, 165-173. DOI: 10.1016/j.baae.2012.12.009.

Löw, J., Buček, A., Lacina, J., Míchal, I., Plos, J. \& Petříček, V. (1995). Rukovět projektanta místniho územního systému ekologické stability. Metodika pro zpracování dokumentace. Brno: Doplněk.

Mack, R. N. \& Erneberg, M. (2002). The United States naturalized flora: largely the product of deliberate introductions. Ann. Missouri Bot. Garden 89, 176-189. DOI: 10.2307/3298562.

Müller, N. \& Waldert, R. (1998). Stadtökologie und Stadtvegetation in Augsburg. In N. Müller (Ed.), Zur Vegetation der Nordalpenvorlandes (pp. 151-168). Augsburg: Dr. Wißner. 
Nordén, B. \& Appelqvist, T. (2001). Conceptual problems of ecological continuity and its bioindicators. Biodivers. Conserv. 10, 779-791. DOI: 10.1023/A:1016675103935.

Peschel, T. (2000). Vegetationskundliche Untersuchungen der Wiesen und Rasen historischer Gärten in Potsdam. Stuttgart: Ibidem-Verlag.

Reichard, S. H. \& White, P. (2001). Horticulture as a pathway of invasive plant introductions in the United States. BioScience, 51, 103-113. DOI: 10.1641/00063568(2001)051[0103:HAAPOI]2.0.CO;2.

Säumel, I., Kowarik, I. \& Butenschön, S. (2010). Green traces from past to future: the interplay of culture and ecological processes in European historical parks. Acta Hortic. 881, 933-938. DOI: 10.17660/ActaHortic.2010.881.156.

Sklenička, P., Molnárová, K., Brabec, E., Kumble, P., Pittnerová, B., Pixová, K. \& Šálek, M. (2009). Remnants of medieval field patterns in the Czech Republic: analysis of driving forces behind their disappearance with special attention to the role of hedgerows. Agr. Ecosyst. Environ. 129, 465-473. DOI: 10.1016/j.agee.2008.10.026.

Sukopp, H. (1968). Das Naturschutzgebiet Pfaueninsel in Berlin-Wannsee. I. Beiträge zur Landschafts- und Florengeschichte. Sitzungsbericht der Gesellschaft Naturforschender Freunde zu Berlin (NF), 8, 93-129.

StatSoft Inc. (2009. September). STATISTICA (data analysis software system), version 9.0. Retrieved September 29, 2015, from http://www.statsoft.com

Šantrůčková, M. (2012). The Principles and Development of Landscape Parks in the Czech Republic and Their Study from the Perspective of Historical Geography. Historická geografie, 38, 99-118.

Šantrůčková, M., Dostálek, J. \& Demková, K. (2015). Assessing long-term spatial changes of natural habitats using old maps and archival sources: a case study from Central Europe. Biodivers. Conserv. 24, 1899-1916. DOI: 10.1007/s10531-015-0912-x.

Šantrůčková, M., Demková, K., Dostálek, J. \& Frantík, T. (2017). Manor gardens: Harbors of local natural habitats? Biol. Conserv. 205, 16-22. DOI: 10.1016/j.biocon.2016.11.005.

Ter Braak, C. J. F. \& Šmilauer, P. (2012). Canoco reference manual and user's guide: software for ordination, version 5.0. Ithaca, USA: Microcomputer Power.

Van Calster, H., Vandenberghe, R., Ruysen, M., Verheyen, K., Hermy, M. \& Decocq, G. (2008). Unexpectedly high 20th century floristic losses in a rural landscape in nothern France. J. Ecol. 96, 927-936. DOI: 10.1111/j.1365-2745.2008.01412.x.

Vojta, J. \& Drhovská, L. (2012). Are abandoned wooded pastures suitable refugia for forest species? J. Veg. Sci. 23, 880-891. DOI: 10.1111/j.1654-1103.2012.01399.x.

Vos, W. \& Meekes, H. (1999). Trends in European cultural landscape development: perspectives for a sustainable future. Landsc. Urban Plan. 46, 3-14. DOI: 10.1016/S0169-2046(99)00043-2.

Walerzak, M. T., Swierk, D., Krzyzaniak, M. \& Urbanski, P. (2015). A method of analysis and valorisation of historic green space arrangements in rural areas in Poland. Bulg. J. Agric. Sci. 21, 507-516. 